\section{Waiting time after non- depolarizing relaxants alter muscle fasciculation response to succinylcholine}

Alfred C. Pinchak PhD PE MD, Charles E. Smith MD FRCPC, Lee S. Shepard MD, Louise Patterson CRNA
The purpose of the study was to determine the effect of nondepolarizing muscle relaxants and waiting time on muscle fasciculations after succinylcholine in anaesthetized patients. Adult men and women, $60-80 \mathrm{~kg}$, received pretreatment doses of atracurium $5 \mathrm{mg}(n=160)$, pancuronium $1 \mathrm{mg}(n=123)$, d-tubocurarine $3 \mathrm{mg}(n=97)$, or vecuronium $1 \mathrm{mg}(n=62)$. Waiting times between pretreatment and succinylcholine, 100 $\mathrm{mg}$, ranged between 0.6 and $5 \mathrm{~min}$. Data points (presence or absence of fasciculations and waiting time) were entered for each patient. Waiting time response curves were obtained between the logit transformation of the probability of no fasciculations and the log waiting time for each drug. Statistical differences between wait time response curves were determined by non-overlapping of the associated $95 \%$ confidence intervals. The frequency of muscle fasciculations was reduced with increased waiting time for all nondepolarizers tested. Following wait times of three, four and five minutes, the probability of not fasciculating was greatest with d-tubocurarine 90,97 and 99\%, respectively) and atracurium (89, 93 and 96\%). Corresponding values for pancuronium were 70,82 and $88 \%$ and for vecuronium were 74,82 and $86 \%$. Waiting times to prevent fasciculations in $80 \%$ and $90 \%$ of patients were shorter with d-tubocurarine (2.46 and $3.02 \mathrm{~min}$, respectively) or atracurium (2.16 and $3.24 \mathrm{~min}$ ) than pancuronium ( 3.77 and $5.35 \mathrm{~min}$ ) or

\section{Key words}

INTERACTIONS (DRUG): neuromuscular relaxants;

NEUROMUSCULAR RELAXANTS: atracurium, pancuronium, succinylcholine, d-tubocurarine, vecuronium.

From the Department of Anesthesiology, MetroHealth Medical Center, Case Western Reserve University, Cleveland, Ohio 44109, USA.

Address correspondence to: Dr. A.C. Pinchak at the Department of Anesthesiology, MetroHealth Medical Center, 2500 MetroHealth Drive, Cleveland, Ohio 44109, USA.

Presented in part at the 4th International Neuromuscular Meeting, Montréal, May, 1992.

Accepted for publication 28th October, 1993. vecuronium (3.73 and $6.36 \mathrm{~min}$ ). In a subgroup of 107 patients who did not fasciculate after succinylcholine, patients receiving $d$-tubocurarine pretreatment had the lowest frequency of cough ing/bucking responses during tracheal intubation (22\%), whereas patients receiving atracurium had the highest frequency (58\%). The data suggest that pretreatment with d-tubocurarine $3 \mathrm{mg}$, using a 3.5 to $4 \mathrm{~min}$ wait time interval is the optimal method to prevent succinylcholine-induced fasciculations.

L'objectif de ce travail est de mesurer l'effet des myarelaxants non dépolarisants sur la vitesse d'apparition des fasciculations musculaires et lintervalle d'attente qui suit l'administration de succinylcholine chez le patient anesthésié. Des adultes des deux sexes, pesant de 60 à $80 \mathrm{~kg}$, reçoivent en pré-traitement de l'atracurium $5 \mathrm{mg}(n=160)$, du pancuronium $1 \mathrm{mg}(n=$ 123), de la d-tubocurarine $3 \mathrm{mg}(n=97)$ ou du vécuronium $1 \mathrm{mg}(n=62)$. L'intervalle entre le pré-traitement et l'administration de succinylcholine $100 \mathrm{mg}$ se situe entre 0,6 et 5 min. Les données de recherche (présence ou absence de fasciculations et lintervalle d'attente) sont enregistrées pour chacun des patients. Des courbes de réponse sont obtenues entre la probabilité transformée en logit de l'absence de fasciculation et le logarithme de lintervalle d'attente. Les différences statistiques entre les courbes-réponses de lintervalle d'attente sont déterminées avec le non-chevauchement des intervalles de confiance à $95 \%$. La fréquence des fasciculations musculaires diminue avec l'augmentation de lintervalle d'attente pour tous les non dépolarisants étudiés. Après un intervalle d'attente de trois, quatres et cinq minutes, la probabilité d'absence de fasciculations est plus élevée avec la d-tubocurarine 190,97 et $99 \%$ respectivement) et l'atracurium (89, 93 et 96\%). Les valeurs correspondantes pour le pancuronium sont de 70,82 et $88 \%$ et pour le vécuronium de 74,82 et $86 \%$. Les intervalles d'attente nécessaires à la prévention des fasciculations chez 80 et $90 \%$ des patients sont plus courts avec la d-tubocurarine $(2,46$ et 3,02 min respectivement) ou l'atracurium $(2,16$ a $3,24 \mathrm{~min})$ que le pancuronium (3,77 et 5,35 min) ou le vécuronium (3,73 et 6,36 min). Dans un sous-groupe de 107 patients sans fasciculations après succinylcholine, les patients qui reçoivent $d-$ tubocurarine ont la plus basse incidence de toux et de cabrade 
à l'intubation (22\%), alors que ceux qui reçoivent de l'atracurium ont lincidence la plus élevée (58\%). Ces donnés suggèrent que la méthode optimale de prévention des fasciculations consiste à injecter de la d-tubocurarine $3 \mathrm{mg}, 3,5$ à 4 min avant la succinylcholine.

Subparalyzing doses of nondepolarizing muscle relaxants are often given prior to succinylcholine to prevent muscle fasciculations and postoperative muscle pains, and to attenuate the increases in intraocular, intragastric and intracranial pressures. ${ }^{1-7}$ Although many different pretreatment regimens to prevent succinylcholine-induced fasciculations have been described, ${ }^{7-9}$ controversy exists about the optimal choice of nondepolarizing relaxant as well as the optimal timing interval between pretreatment and succinylcholine administration. Moreover, defasciculating doses of nondepolarizing relaxants may delay the onset and decrease the intensity of succinylcholine-induced neuromuscular blockade. ${ }^{2}$ The purpose of the study was to determine the frequency of muscle fasciculations after a standard dose of succinylcholine in adult patients pretreated at varying time intervals with small doses of atracurium, pancuronium, d-tubocurarine or vecuronium. The study has clinical relevance because muscle fasciculations after succinylcholine have been associated with postoperative myalgia as well as muscle damage, although it is acknowledged that other factors unrelated to succinylcholine and/or fasciculations may also result in myalgia and muscle damage. ${ }^{10-17}$

\section{Methods}

Four hundred and forty-two patients (weight range 60-80 $\mathrm{kg}$ ) undergoing elective surgery requiring general anaesthesia, tracheal intubation and muscle relaxation were prospectively studied. The study was approved by the Hospital Institutional Review Board under a monitoring protocol. Exclusion criteria included: abnormal airway, suspected difficult intubation, atypical plasma cholinesterase, malignant hyperthermia, increased intraocular or intracranial pressure, hyperkalaemia and known or suspected sensitivity to depolarizing and nondepolarizing muscle relaxants. Premedication was at the discretion of the anaesthetist and generally consisted of a narcotic and/ or midazolam. After placement of routine monitors, a standard pretreatment dose of atracurium $5 \mathrm{mg}$, pancuronium $1 \mathrm{mg}$, d-tubocurarine $3 \mathrm{mg}$ or vecuronium 1 $\mathrm{mg}$ was given $i v$. Pretreatment doses were the ones used most often clinically in our institution, although they were not equipotent. Anaesthesia was induced with thiopentone $3-5 \mathrm{mg} \cdot \mathrm{kg}^{-1}$, and the patients' lungs were ventilated with oxygen. Direct laryngoscopy and tracheal intubation were performed one minute after succinylcholine $100 \mathrm{mg}$ $\dot{i}$. The precise waiting time between pretreatment and succinylcholine was determined by the anaesthetist and ranged from 0.6 to $5.0 \mathrm{~min}$. Criteria for fasciculations were the visible presence of contractions of the trunk, face and/or extremities. Generally, these observations were made by two observers, one of whom was unaware of the pretreatment drug. Fasciculations were graded as absent only if no visible fasciculations were observed. The presence or absence of fasciculations after succinylcholine was recorded and analyzed with respect to wait time, drug, age and sex using the categorical model procedure and Chi Square analysis (SAS software). Waiting time response curves (WTRC) for each relaxant were estimated and plotted with the probability of no fasciculations versus log waiting time (probit analysis with logistic and maximum likelihood options, SAS software). The absence of fasciculations was considered a 0 response, whereas the presence of fasciculations was considered a response of 1 . Data points were entered for each individual patient. The estimated waiting times to prevent fasciculations in $50 \%, 80 \%$ and $90 \%$ of patients (WT50, WT80, WD90) were calculated for each drug from probit analysis of the wait time-response relationship. The probability of not fasciculating after wait time intervals of two, three, four and five minutes following each nondepolarizing relaxant were also computed from the probit analysis using the method of Hosmer and Lemeshow. ${ }^{18}$ Statistically significant differences were determined by non-overlapping of the $95 \%$ confidence intervals estimated from the wait time-response probit analysis. The presence or absence of coughing or bucking during tracheal intubation was also recorded and analyzed with respect to nondepolarizing drug and demographics using the categorical model procedure and ChiSquare analysis (SAS software) in a subgroup of 107 patients not fasciculating after succinylcholine. Criteria for the presence of coughing or bucking were patient generated movement of the chest, abdomen or head during tracheal intubation. Data were expressed as mean values \pm SEM. A $P$ value of $<0.05$ was considered significant.

\section{Results}

There were no differences in age, sex, or weight between groups (Table I). The incidence of fasciculations was 16 , 37,16 and $26 \%$ in the atracurium, pancuronium, $d-$ tubocurarine and vecuronium groups, respectively. Chisquare analysis of observer(s) vs presence or absence of muscle fasciculations did not reveal any influence of observer $(P>0.2)$. The distribution of wait times was nonuniform with respect to the four non-depolarizing relaxants, but was homogenous with respect to age, weight and sex (Table II). There was a greater percentage of 
TABLE I Demographic data (Mean \pm SEM)

\begin{tabular}{lllll}
\hline & & $\begin{array}{l}\text { Age } \\
(y r)\end{array}$ & $\begin{array}{l}\text { Sex } \\
M / F\end{array}$ & $\begin{array}{l}\text { Weight } \\
(\mathrm{kg})\end{array}$ \\
\hline Atracurium & 160 & $37 \pm 1$ & $60 / 100$ & $69 \pm 1$ \\
Pancuronium & 123 & $39 \pm 2$ & $48 / 75$ & $70 \pm 1$ \\
d-Tubocurarine & 97 & $37 \pm 2$ & $37 / 60$ & $69 \pm 1$ \\
Vecuronium & 62 & $41 \pm 2$ & $25 / 37$ & $69 \pm 1$ \\
\hline
\end{tabular}

TABLE II Number of patients receiving nondepolarizing relaxants at various waiting time intervals. Bracketed numbers correspond to the number of patients fasciculating.

\begin{tabular}{lccccc}
\hline & $0-1 \min$ & $1-2 \min$ & $2-3 \min$ & $3-4 \min$ & $4-5 \min$ \\
\hline Atracurium & $3(1)$ & $37(13)$ & $39(6)$ & $47(4)$ & $34(2)$ \\
Pancuronium & $3(2)$ & $30(19)$ & $38(14)$ & $27(6)$ & $25(4)$ \\
d-Tubocurarine & $0(0)$ & $8(5)$ & $45(10)$ & $26(1)$ & $18(0)$ \\
Vecuronium & $1(1)$ & $9(4)$ & $8(2)$ & $17(4)$ & $17(5)$ \\
\hline
\end{tabular}

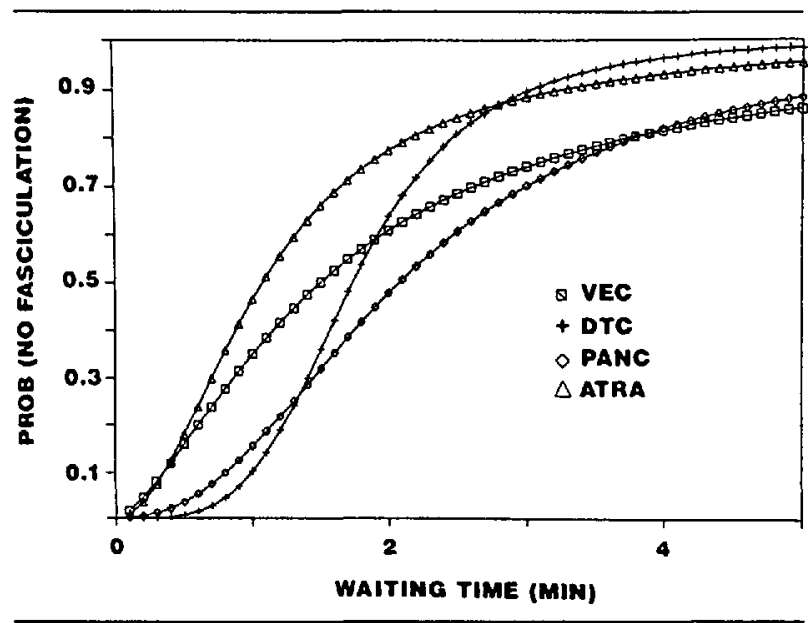

FIGURE I Waiting time response curves showing the probability of no fasciculations vs waiting time for patients receiving pretreatment with atracurium, pancuronium, d-tubocurarine and vecuronium.

patients in the three to four minute wait time interval in the vecuronium pretreatment group than in the other three groups, whereas there was a greater percentage of patients in the two- to three-minute wait time interval in the d-tubocurarine group. The probability of fasciculations after succinylcholine was affected by nondepolarizing agent $(P<0.05)$ and wait time $(P<0.001$, Figure 1). D-tubocurarine and atracurium were more potent in blocking succinylcholine fasciculations in 80 and $90 \%$ of cases than were pancuronium or vecuronium ( $P$ $<0.05$ for WT80, Table III). Following a standard wait time of two, three, four and five minutes, the probability of not fasciculating was greatest with d-tubocurarine and atracurium compared with pancuronium and vecuronium (Table IV). Compared with pancuronium, d-tubocurarine
TABLE III Estimated wait times (minutes) to prevent fasciculation in $50 \%, 80 \%$, and $90 \%$ of patients (WT50, WT80, WT90) after a standard dose of succinylcholine

\begin{tabular}{|c|c|c|c|c|}
\hline \multirow[b]{2}{*}{ Drug } & \multirow{2}{*}{$\begin{array}{l}\% \text { Patients not } \\
\text { fasciculating }\end{array}$} & \multirow{2}{*}{$\begin{array}{l}\text { Waiting } \\
\text { time }\end{array}$} & \multicolumn{2}{|c|}{$95 \%$ Confidence limits } \\
\hline & & & Lower & Upper \\
\hline \multirow[t]{3}{*}{ Atracurium } & WT50 & 1.12 & 0.48 & 1.52 \\
\hline & WT80 & $2.20^{*}$ & 1.69 & 2.81 \\
\hline & WT90 & 3.26 & 2.60 & 5.45 \\
\hline \multirow[t]{3}{*}{ Pancuronium } & WT50 & 2.08 & 1.54 & 2.47 \\
\hline & WT80 & 3.77 & 3.11 & 5.70 \\
\hline & WT90 & 5.35 & 4.06 & 10.73 \\
\hline \multirow[t]{3}{*}{ d-tubocurarine } & WT50 & 1.73 & 1.11 & 2.07 \\
\hline & WT80 & $2.46^{*}$ & 2.05 & 2.97 \\
\hline & WT90 & 3.02 & 2.58 & 4.18 \\
\hline \multirow[t]{3}{*}{ Vecuronium } & WT50 & 1.50 & $\mathrm{~N} / \mathrm{A}$ & 2.32 \\
\hline & WT80 & 3.73 & 2.40 & N/A \\
\hline & WT90 & 6.36 & 3.89 & N/A \\
\hline
\end{tabular}

${ }^{*} P<0.05$ vs pancuronium.

N/A: estimate not computed.

TABLE IV Probability of not fasciculating after succinylcholine at standard wait times

\begin{tabular}{|c|c|c|c|c|}
\hline \multirow[b]{2}{*}{ Drug } & \multirow{2}{*}{$\begin{array}{l}\text { Wait time } \\
\text { (min) }\end{array}$} & \multirow[b]{2}{*}{ Probability } & \multicolumn{2}{|c|}{$95 \%$ Confidence limits } \\
\hline & & & Lower & Upper \\
\hline \multirow[t]{4}{*}{ Atracurium } & 2 & $0.77^{*}$ & 0.67 & 0.84 \\
\hline & 3 & 0.88 & 0.81 & 0.93 \\
\hline & 4 & 0.93 & 0.86 & 0.97 \\
\hline & 5 & 0.96 & 0.89 & 0.98 \\
\hline \multirow[t]{4}{*}{ Pancuronium } & 2 & $0.48^{*}$ & 0.36 & 0.60 \\
\hline & 3 & 0.70 & 0.60 & 0.78 \\
\hline & 4 & 0.82 & 0.71 & 0.90 \\
\hline & 5 & 0.88 & 0.77 & 0.95 \\
\hline \multirow[t]{4}{*}{ d-tubocurarine } & 2 & $0.64^{*}$ & 0.46 & 0.79 \\
\hline & 3 & 0.90 & 0.81 & 0.95 \\
\hline & 4 & $0.97 \dagger$ & 0.89 & 0.99 \\
\hline & 5 & 0.99 & 0.93 & 1.00 \\
\hline \multirow[t]{4}{*}{ Vecuronium } & 2 & $0.61^{*}$ & 0.40 & 0.78 \\
\hline & 3 & 0.74 & 0.61 & 0.84 \\
\hline & 4 & 0.82 & 0.68 & 0.90 \\
\hline & 5 & 0.86 & 0.70 & 0.94 \\
\hline
\end{tabular}

$* P<0.05$ vs 4 and 5 min wait times (within groups).

$\dagger P<0.05$ vs pancuronium $4 \mathrm{~min}$ (between groups).

was more potent in preventing fasciculations at the fourminute wait times. Overall, men were more likely to fasciculate than women $(33 \%$ of 170 patients vs $17 \%$ of 272 patients, $P<0.001$ ). Within the pancuronium group, men were more likely to fasciculate than women at the shorter wait times ( $<3 \mathrm{~min}$, Figure 2), although a sexrelated difference was not noted for the other nondepolarizers. Patients receiving d-tubocurarine pretreatment 


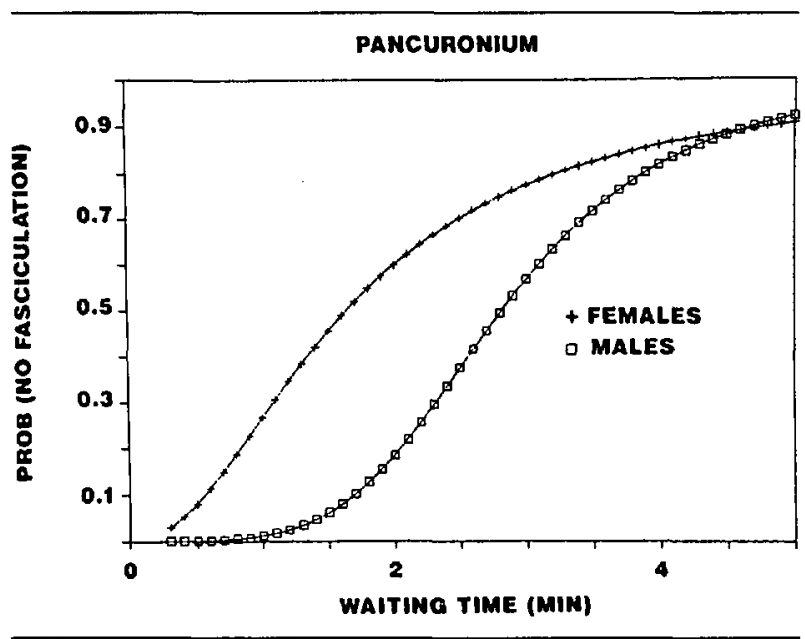

FIGURE 2 Waiting time response curves showing the probability of no fasciculations vs waiting time for men and women receiving pancuronium pretreatment.

had the lowest frequency of coughing/bucking responses during intubation, whereas patients receiving atracurium had the highest frequency $P<0.01$, Figure 3). Age and weight did not affect the incidence of fasciculations or response to intubation. There was no effect of sex on response to intubation.

\section{Discussion}

The present study demonstrated that the probability of developing muscle fasciculations after succinylcholine is highly dependent on waiting time interval and nondepolarizing drug. D-tubocurarine was the most potent in inhibiting succinylcholine-induced fasciculations, followed by atracurium, pancuronium and vecuronium. Despite wait times of four to five minutes, the probability of not fasciculating with vecuronium and pancuronium pretreatment never exceeded 0.9. This explains the high estimated waiting times required to prevent fasciculations (in $90 \%$ of patients) for vecuronium and pancuronium (WT90 = 6.36 and 5.35 minutes, respectively), as well as the inability to compute upper confidence limits for the estimated wait times with vecuronium pretreatment. In contrast, after a four to five minute wait time, the probability of not fasciculating with d-tubocurarine pretreatment was almost 1.0. Thus, the WT90 of 3.02 minutes for dtubocurarine was the shortest wait time of the four nondepolarizers studied.

The probit model was chosen to characterize the response to different waiting times because preliminary data at our institution, as well as data in the literature, ${ }^{8}$ suggested that the relationship describing the probability of not fasciculating vs waiting time would have a sigmoidal shape, similar to dose-response data. At short wait times the probability of preventing fasciculations would be low

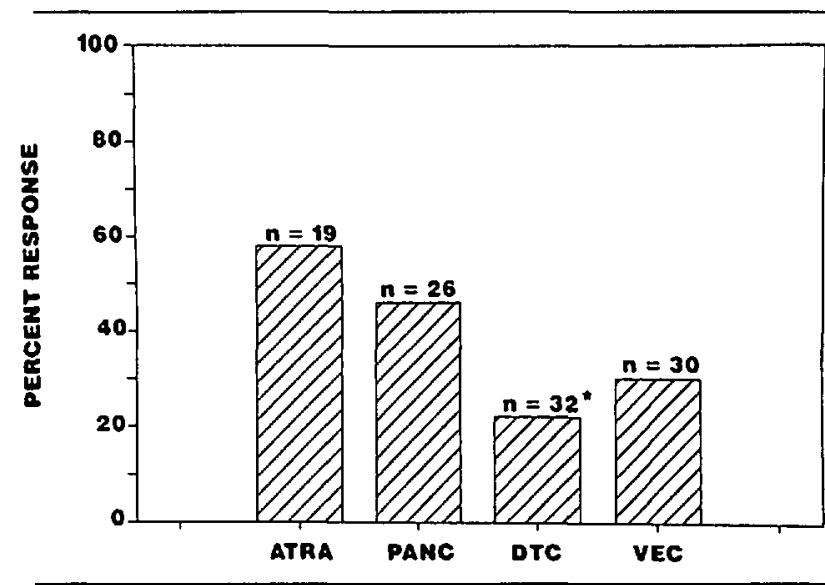

FIGURE 3 Relative frequency of coughing/bucking response after defasciculation doses of atracurium, pancuronium, d-tubocurarine and vecuronium. ${ }^{*} P<0.01$ vs atracurium.

because not enough time had elapsed to allow for adequate drug concentration at the effector site. At longer wait times, the probability of no fasciculations would gradually approach 1.0. Probit calculations provided estimates and $95 \%$ confidence limits for: (1) WT50, WT80 and WT90, and (2) the probability of not fasciculating after a specified wait time. As relatively few patients were in the zero to one minute wait time interval, it may be incorrect to assume that all patients will exhibit fasciculations if the wait time is zero. However, probit models fit with a nonzero threshold rate, all demonstrated a less satisfactory goodness-of-fit than models which assumed that all patients fasciculate at a wait time of zero.

The lack of randomization with respect to waiting time and precurarizing agent was a flaw in the design utilized in the present study. Although the distributions of wait times were non-uniform with respect to the four relaxants, they were homogeneous with respect to age, weight and sex. Thus, it was unlikely that patient characteristics could have accounted for the differences in response observed in the present study. There was a greater percentage of patients in the longer wait time intervals in the vecuronium group (three to four minutes) and a greater percentage of patients in the shorter wait time interval in the d-tubocurarine group (two to three minutes). However, if vecuronium was really a better agent than dtubocurarine in preventing fasciculations, one could speculate that this unequal distribution should favour vecuronium over d-tubocurarine (which was not the case) because longer wait times increase the likelihood of equilibration of the nondepolarizer at the effector site, thereby decreasing the probability of muscle fasciculations. The non-uniformity of waiting time distributions resulted in relatively fewer data points at either low or high values of the waiting time. Although this non- 
uniformity could influence the overlapping of the 95\% confidence intervals, it was unlikely to alter the shape of the waiting time response curves. This is because the confidence limits were wider at these extreme values, making it more difficult to achieve a non-overlapping condition. Although the study was not blinded, observations were generally made by two observers, one of whom was unaware of the pretreatment drug. Moreover, the criteria measured in the study, fasciculations and response to tracheal intubation, were well-defined and were evaluated by anaesthetists with many years of clinical experience. As well, retrospective analysis of observer versus response did not reveal any influence of observer. It should be noted that the doses of nondepolarizing relaxants employed in the present study were chosen because of familiarity and ease of administration in the clinical setting and were not equipotent. For example the $3 \mathrm{mg}$ dose of d-tubocurarine only represented $16 \%$ of the $\mathrm{ED}_{50}$ in a $70 \mathrm{~kg}$ patient $\left(3 \mathrm{mg} \cdot 70 \mathrm{~kg}^{-1}=0.043\right.$ $\mathrm{mg} \cdot \mathrm{kg}^{-1}$ divided by an $\mathrm{ED}_{50}$ of $\left.0.26 \mathrm{mg} \cdot \mathrm{kg}^{-1}\right)$, whereas the $5 \mathrm{mg}$ dose of atracurium was $60 \%$ of the $E_{50}\left(5 \mathrm{mg} \cdot 70 \mathrm{~kg}^{-1}=0.07 \mathrm{mg} \cdot \mathrm{kg}^{-1}\right.$ divided by an $\mathrm{ED}_{50}$ of $\left.0.12 \mathrm{mg} \cdot \mathrm{kg}^{-1}\right) .{ }^{19}$ Corresponding fractions of the pretreatment doses of pancuronium and vecuronium used in the study were 48 and $62 \%$ of the $\mathrm{ED}_{50}$, respectively (assuming an $\mathrm{ED}_{50}$ of $0.023 \mathrm{mg} \cdot \mathrm{kg}^{-1}$ for pancuronium and $0.03 \mathrm{mg} \cdot \mathrm{kg}^{-1}$ for vecuronium). ${ }^{19,20}$ Nevertheless, despite the lower $\mathrm{mg} \cdot \mathrm{kg}^{-1}$ dose of d-tubocurarine, this drug still appeared more effective in preventing fasciculations compared with the higher $\mathrm{mg} \cdot \mathrm{kg}^{-1}$ doses of atracurium, pancuronium and vecuronium.

The higher probability of fasciculating at the shorter wait times suggests that the onset of defasciculating action of nondepolarizers at the prejunctional acetylcholine receptor is governed in a similar fashion to the onset of neuromuscular blockade at the postjunctional receptor. It has been demonstrated that differences in drug potency may influence receptor binding and onset of neuromuscular blockade. ${ }^{21}$ For example, the speed of action of nondepolarizing relaxants at the postjunctional acetylcholine receptor has been shown to be inversely proportional to drug potency. ${ }^{22}$ It is possible that the speed of action of nondepolarizers at the prejunctional receptors may also be governed by potency in an inverse fashion. Thus, a low potency drug such as d-tubocurarine $\left(E D_{50} 0.26\right.$ $\left.\mathrm{mg} \cdot \mathrm{kg}^{-1}\right)^{7}$ had a faster onset of defasciculating action than a higher potency drug such as vecuronium or pancuronium $\left(\mathrm{ED}_{50} 0.023\right.$ and $0.03 \mathrm{mg} \cdot \mathrm{kg}^{-1}$, respectively). ${ }^{19,20}$ Similarly, the rate of onset of defasciculation from equipotent doses of atracurium (intermediate potency, $\left.\mathrm{ED}_{50} 0.12 \mathrm{mg} \cdot \mathrm{kg}^{-1}\right)^{19}$ was faster than that of vecuronium and pancuronium, but slower than $d-$ tubocurarine. Because of the very low potency of gal-

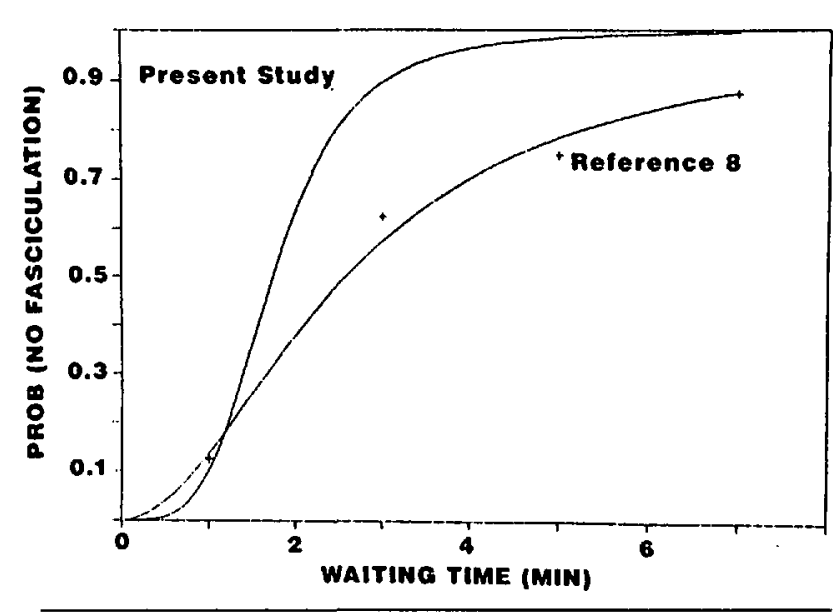

FIGURE 4 Waiting time response curves showing the probability of no fasciculations vs waiting time after pretreatment with dtubocurarine. The curve from the present study is compared with the curve constructed using data from Horrow and Lambert. ${ }^{8}$

lamine $\left(\mathrm{ED}_{50} 0.76 \mathrm{mg} \cdot \mathrm{kg}^{-1}\right)$, ${ }^{23}$ subparalyzing doses of this nondepolarizer would be expected to prevent fasciculations reliably, even at relatively short wait times. Indeed, small doses of this agent have been reported to prevent fasciculations in the majority of patients when given 0.5 to one minute before succinylcholine. ${ }^{24,25} \mathrm{Sim}$ ilarly, it is not surprising that a higher potency drug such as pancuronium has been shown to be less effective in preventing succinylcholine-induced fasciculations than low potency agents such as gallamine and $\mathrm{d}$ tubocurarine. ${ }^{2,3}$ It is possible that the greater affinity of d-tubocurarine and atracurium for the prejunctional receptors than pancuronium and vecuronium could account for the lower probability of fasciculations with dtubocurarine and atracurium observed in the study. ${ }^{26,27}$

It has been stated by Horrow and Lambert that the optimal interval between pretreatment with dtubocurarine $3 \mathrm{mg} \cdot 70 \mathrm{~kg}^{-1}$ and succinylcholine, 1.5 $\mathrm{mg} \cdot \mathrm{kg}^{-1}$, is three minutes and that no additional benefit in preventing fasciculations is obtained with longer intervals such as five and seven minutes. ${ }^{8}$ However, calculation of WTRC from their data suggests that the probability of preventing succinylcholine-induced fasciculations was improved with longer waiting time intervals, with an $88 \%$ chance of not fasciculating at seven minutes, $84 \%$ at six minutes, $79 \%$ at five minutes, $70 \%$ at four minutes, $58 \%$ at three minutes and $38 \%$ at two minutes (Figure 4).

The higher incidence of coughing and bucking during tracheal intubation in the atracurium, pancuronium and vecuronium subgroups of nonfasciculating patients than in the d-tubocurarine subgroup was probably due to greater antagonism of depolarizing block associated with 
the higher $\mathrm{mg} \cdot \mathrm{kg}^{-1}$ dose of nondepolarizer. Although not addressed in this study, it should be noted that subparalyzing doses of nondepolarizers may result in blurred vision, heavy eyelids, as well as difficulty in breathing and maintaining an airway. Therefore, the pretreatment dose should be as small as possible (i.e., for a $70 \mathrm{~kg}$ patient, d-tubocurarine $3 \mathrm{mg}$, atracurium $2 \mathrm{mg}$, pancuronium $0.5 \mathrm{mg}$, vecuronium $0.5 \mathrm{mg}$ ). Use of adjuvant agents such as diphenylhydantoin, diazepam and/or lidocaine may also be helpful in suppressing fasciculations due to stabilization of motor nerve terminals by a mechanism unrelated to the acetylcholine receptor. $5,28,29$

In summary, the effectiveness of nondepolarizing muscle relaxants in preventing succinylcholine-induced muscle fasciculations was highly dependent on the wait time interval and choice of nondepolarizing drug. The frequency of muscle fasciculations was reduced when the waiting time interval between pretreatment and succinylcholine was increased, regardless of drug used. Pretreatment with d-tubocurarine and atracurium appeared to be more effective in preventing muscle fasciculations than pancuronium or vecuronium. However, atracurium pretreatment was associated with a higher incidence of coughing and bucking during intubation compared with d-tubocurarine. The data suggest that pretreatment with d-tubocurarine using a 3.5 to four minute wait time interval is the optimal method to prevent fasciculations after succinylcholine.

\section{Acknowledgement}

The authors would like to thank Jong C. Sung MD, Joan F. Hagen BA and Fran Hall for their dedicated assistance in this study.

\section{References}

1 Erkola $O$, Salmenperä A, Kuoppamäki $R$. Five nondepolarizing muscle relaxants in precurarization. Acta Anaesthesiol Scand 1983; 27: 427-32.

2 Cullen DJ. The effect of pretreatment with nondepolarizing muscle relaxants on the neuromuscular blocking action of succinylcholine. Anesthesiology 1971; 35: 572-8.

3 Blitt CD, Carlson GL, Rolling GD, Hameroff $S R$, Otto $C W$. A comparative evaluation of pretreatment with nondepolarizing blockers prior to the adminstration of succinylcholine. Anesthesiology 1981; 55: 687-9.

4 Bennetts FE, Khalil KI. Reduction of postsuxamethonium pain by pretreatment with four nondepolarizing agents. $\mathrm{Br} \mathrm{J}$ Anaesth 1981; 53: 531-6.

5 Miller RD, Way $W L$. Inhibition of succinylcholineinduced increased intragastric pressure by nondepolarizing muscle relaxants and lidocaine. Anesthesiology $1971 ; 34$ : 185-8.

6 Stirt $J A$, Grosslight $K R$, Bedford $R F$, Vollmer D. "Defas- ciculation" with metocurine prevents succinylcholineinduced increases in intracranial pressure. Anesthesiology 1987; 67: 50-3.

7 Bevan DR, Bevan JC, Donati F. Muscle Relaxants in Clinical Anesthesia. Chicago: Year Book Medical Publishers, 1988.

8 Horrow JC, Lambert DH. The search for an optimal interval between pretreatment dose of d-tubocurarine and succinylcholine. Can Anaesth Soc J 1984; 31: 528-33.

9 Miller RD, Way WL. The interaction between succinylcholine and subparalyzing doses of d-tubocurarine and gallamine in man. Anesthesiology 1971; 35: 567-71.

10 McLoughlin C, Elliott P, McCarthy G, Mirakhur RK. Muscle pains and biochemical changes following suxamethonium administration after six pretreatment regimens. Anaesthesia 1992; 47: 202-6.

11 Manchikanti L, Grow JB, Colliver JA, Canella MG, Hadley $\mathrm{CH}$. Atracurium pretreatment for succinylcholineinduced fasciculations and postoperative myalgia. Anesth Analg 1985; 64: 1010-4.

12 Domaoal AM, Weniger FC, Wolfson B. "Precurarization" using pancuronium. Anesth Analg 1975; 54: 71-5.

13 White $D C$. Observations on the prevention of muscle pains after suxamethonium. $\mathrm{Br} \mathrm{J}$ Anaesth 1962; 34: 332-5.

14 Pace NL. Prevention of succinylcholine myalgias: a metaanalysis. Anesth Analg 1990; 70: 477-83.

15 Sosis M, Broad T, Larijani GE, Marr AT. Comparison of atracurium and d-tubocurare for prevention of succinylcholine myalgias. Anesth Analg 1987; 66: 657-9.

16 Zahl K, Apfelbaum JL. Muscle pain occurs after outpatient laparoscopy despite the substitution of vecuronium for succinylcholine. Anesthesiology 1989; 70: 408-11.

17 Collins KM, Docherty PW, Plantevin OM. Postoperative morbidity following gynaecological outpatient laparoscopy. A reappraisal of the service. Anaesthesia 1984; 39: 819-22.

18 Hosmer DW Jr., Lemeshow S. Applied Logistic Regression. New York: John Wiley \& Sons, 1989.

19 Smith CE, Donati F, Bevan DR. Cumulative doseresponse with infusioin: a technique to determine neuromuscular blocking potency of atracurium and vecuronium. Clin Pharmacol Ther 1988; 44: 56-64.

20 Smith CE, Donati F, Bevan DR. Differential effects of pancuronium on masseter and adductor pollicis muscles in humans. Anesthesiology 1989; 71: 57-61.

21 Bartowski RB, Epstein RH. The influence of receptor binding on the onset of neuromuscular blockade. (Abstract). Fourth International Neuromuscular Meeting, Montreal, 1992 2C.

22 Law Min JC, Bekavac I, Glavinovic MI, Donati F, Bevan $D R$. Iontophoretic study of speed of action of various muscle relaxants. Anesthesiology 1992; 77: 351-6. 
23 Donlon JV, Ali HH, Savarese JJ. A new approach to the study of four nondepolarizing relaxants in man. Anesth Analg 1974; 53: 934-9.

24 Virtue RW. Comparison of gallamine with d-tubocurarine effects on fasciculation after succinylcholine. Anesth Analg 1975; 54: 81-2.

25 Ferres CJ, Mirakhur RK, Craig HJL, Browne ES, Clarke $R S J$. Pretreatment with vecuronium as a prophylactic against post-suxamethonium muscle pain. Comparison with other non-depolarizing neuromuscular blocking drugs. Br J Anaesth 1983; 55: 735-40.

26 Bowman WC. Prejunctional and postjunctional cholinoceptors at the neuromuscular junction. Anesth Analg 1980; 59: 935-43.

27 Gibson FM, Mirakhur RK. Train-of-four fade during onset of neuromuscular block with nondepolarizing neuromuscular blocking agents. Acta Anaesthesiol Scand 1989; 33: 204-6.

28 Hartman GS, Fiamengo SA, Riker WF Jr. Succinylcholine: mechanism of fasciculations and their prevention by $\mathrm{d}$ tubocurarine or diphenylhydantoin. Anesthesiology 1986; 65: 405-13.

29 Fahmy NR, Malek MS, Lappas DG. Diazepam prevents some adverse effects of succinylcholine. Clin Pharmacol Ther 1979; 26: 395-8. 